\title{
Examining SNS marketing characteristics affecting brand image and repurchase intention
}

\author{
Jaehun Joo* and Chunglo Kim \\ Department of Management, Dongguk University-Gyeongju, Dongdaero-123, Sukjang-dong, \\ Gyeongju, Gyeongbuk, South Korea
}

Keywords: Social network service, SNS marketing; Brand image, Intention, Structural equation modeling.

\begin{abstract}
SNS (Social Network Service) marketing which is a promising marketing based social media such as Facebook, Instagram, Twitter, blog, and Youtube is a critical management activity for online advertising, promotion, sales, and demand creation. What kinds of SNS marketing characteristics are antecedents of brand image and repurchase intention. The present study proposes a new research model integrating SNS marketing characteristics, brand image, and customers' repurchase intention and tests four hypotheses. Finally, the present paper presents academics and practitioners.
\end{abstract}

\section{Introduction}

Social media or SNS (Social Network Service) media such as Facebook, Instagram, Twitter, blog, Youtube, and Wiki becomes a new marketing approach or tool. SNS or social media enables social interaction and personalized marketing \& services through digitalization and two-way communication. In the present study, SNS is interchangeably used with social media. SNS marketing plays a critical role in advertising, promotion, and demand creation. It is necessary to identify the SNS marketing characteristics contributing to brand image and customers' repurchase intention. Thus, the purpose of the present study is to examine what kinds of SNS marketing characteristics are antecedents of brand image and repurchase intention. The present study proposes a new research model integrating SNS marketing characteristics, brand image, and customers' repurchase intention and tests four hypotheses by using structural equation modeling. Data collected from SNS users are used to test four hypotheses.

\section{Theoritical background and research hypothesis}

Many studies argue that SNS like Facebook, Twitter, Instagram, and Pinterest affects brand

\footnotetext{
* Corresponding author: givej@,dongguk.ac.kr
} 
loyalty, awareness on firms, marketing communications, interactivity, and customer participation (Belch and Belch, 2013; Distaso et al., 2015; Ferguson and Greer, 2015). According to Shin et al. [6], hashtags of SNS positively affect product brands through electronic word-of-mouth. Informative advertising increases brand image and purchase intentions (Akpinar and Berger, 2017). According to Lee et al., 2017), informative posts on the Web increase clicks on linked websites. Lee and Hong [4] defined informativeness as "the extent to which SNS messages offer information users perceive as useful." Interactivity in social media has a positive influence on brand loyalty and purchase intention (Kim and Lee, 2019). According to Lin and Chang (2018), perceived interactivity in social media consists of human-to-human interaction and human-to-information interaction. Lin and Chang (2018) defined "perceived interactivity as the extent to which users perceive their experiences as a simulation of interpersonal inter-action and sense that they are in the presence of another user in a social setting." Interactivity in SNS can be measured by average number of posts made by organizations, likes, comments, shares, and consumer posts answered by organizations. Playfulness in messaging service increases word-of-mouth intention (Hsieh and Tseng, 2017).

Three characteristics of SNS such as informativeness, interactivity, and playfulness increase brand image and brand image has a positive influence on repurchase intention of products presented in SNS. Thus, the present study proposes a new research model as shown in Figure 1 and four hypotheses.

Fig. 1 shows the research model derived from extant studies and four hypotheses.

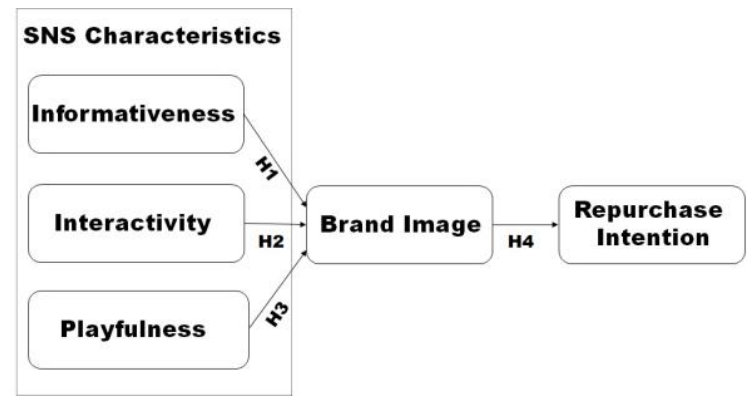

Fig. 1. Research model.

H1: Informativeness on characteristics of SNS marketing has a positive influence on brand image.

$\mathrm{H} 2$ : Interactivity characteristics of SNS marketing has a positive influence on brand image.

H3: Playfulness characteristics of SNS marketing has a positive influence on brand image.

$\mathrm{H} 4$ : Brand image has a positive influence on repurchase intention.

\section{Methodology and analysis}

Measurements regarding a total of four constructs with 16 question items were employed for final survey. All measurement items were measured by five-point Likert scales ranging from 1 (strongly disagree) to 5 (strongly agree). Data were collected from SNS users from June 4, 2019 to July 10, 2019. A total of 199 valid returned samples were collected for analysis.

SPSS Statistics (version 23) and Smart PLS (version 3.2.7, Ringle et al. 2015) were employed to analyze the data. Table 1 shows the demographic characteristics of respondents. $58 \%$ of respondents were female and $51 \%$ of respondents were aged 20 to 39 years. $60 \%$ of respondents have used SNS for more than 5 years. 
Table 1. Demographic characteristics.

\begin{tabular}{|c|c|c|c|}
\hline Variable & Categories & Frequency & Percentage \\
\hline \multirow{2}{*}{ Gender } & Male & 84 & 42.2 \\
\hline & Female & 115 & 57.8 \\
\hline \multirow{5}{*}{ Age } & $20-29$ & 39 & 19.6 \\
\hline & $30-39$ & 63 & 31.7 \\
\hline & $40-49$ & 58 & 29.1 \\
\hline & $50-59$ & 32 & 16.1 \\
\hline & Over 60 & 7 & 3.5 \\
\hline \multirow{5}{*}{ Experience } & Under 1 year & 9 & 4.5 \\
\hline & $1-3$ years & 25 & 12.6 \\
\hline & $3-5$ years & 46 & 23.1 \\
\hline & 5-10 years & 80 & 40.2 \\
\hline & Over 10 years & 39 & 19.6 \\
\hline
\end{tabular}

Table 2 shows SNS types which have been used by respondents. The percentages of Facebook an Instagram are 69\% and 61\% respectively, allowing multiple responses.

Table 2. SNS Types.

\begin{tabular}{|l|l|l|}
\hline SNS & Frequency & Percent \\
\hline Facebook & 137 & 68.8 \\
\hline Instagram & 122 & 61.3 \\
\hline Kakaostory & 107 & 53.8 \\
\hline Naver Band & 83 & 41.7 \\
\hline Daum or Naver Cafe & 97 & 48.7 \\
\hline Blog & 70 & 35.2 \\
\hline Others & 11 & 5.5 \\
\hline
\end{tabular}

Table 3 shows Cronbach's alpha, composite reliability, and average variance extracted (AVE). All Cronbach's alphas exceed the 0.7 threshold for internal consistency. Composite reliabilities (CRs) for all constructs also exceed a cutoff value of 0.7 . Thus, reliability and convergent validity of the model are satisfactory.

Table 3. Internal consistency and convergent validity.

\begin{tabular}{|l|l|l|l|}
\hline Variable & Cronbach's alpha & Composite reliability & AVE \\
\hline Information & 0.801 & 0.869 & 0.625 \\
\hline Interaction & 0.730 & 0.829 & 0.549 \\
\hline Enjoyment & 0.839 & 0.892 & 0.675 \\
\hline Brand Image & 0.866 & 0.909 & 0.714 \\
\hline Intention & 0.895 & 0.927 & 0.761 \\
\hline
\end{tabular}

Table 4 shows the inter-construct correlations and the square root of AVE for each construct. The bold values in diagonal cells indicate the square root of AVE. The square root of AVE for each construct is higher than its correlations with other constructs. According to the Fornell and Larcker criterion, discriminant validity is satisfactory. 
Table 4. Discriminat validity: Fornell-Larcker criterion.

\begin{tabular}{|l|l|l|l|l|l|}
\hline Construct & Information & Interaction & Enjoyment & Brand Image & Intention \\
\hline Information & $\mathbf{0 . 7 9 0}$ & & & & \\
\hline Interaction & 0.629 & $\mathbf{0 . 7 4 1}$ & & & \\
\hline Enjoyment & 0.705 & 0.742 & $\mathbf{0 . 8 2 1}$ & & \\
\hline Brand Image & 0.631 & 0.680 & 0.774 & $\mathbf{0 . 8 4 5}$ & \\
\hline Intention & 0.638 & 0.673 & 0.760 & 0.756 & $\mathbf{0 . 8 7 2}$ \\
\hline
\end{tabular}

In general, when using PLS, the standardized root mean square residual (SRMR) is used as a measure of approximate fit of the structural model. The structural model has good fit because the SRMR value of 0.070 is below the cutoff of 0.08 .

R-squared, known as the coefficient of determination, is measured by the variance explained through the model. Chin [60] classified the levels of explanatory power into "substantial", "moderate", and "weak", with cutoff thresholds of 0.67, 0.33, and 0.19, respectively [60 (p. 323), 68]. R-squared value of brand image is 0.631 exceeding the 0.33 cutoff value. In particular, brand image explains $51 \%$ of the variance in repurchase intention as an endogenous variable.

As shown in Table 5, all hypotheses were supported. H1 and H2 were supported at the significance level of 0.05 and Hypotheses, $\mathrm{H} 3$ to $\mathrm{H} 4$ were supported at the significance level of 0.01 .

Table 5. Path coefficients and results of hypothesis testing.

\begin{tabular}{|c|l|r|c|r|r|c|}
\hline Hypothesis & Path & \multicolumn{1}{c|}{$\begin{array}{c}\text { Path } \\
\text { coefficient }\end{array}$} & SD & \multicolumn{1}{c|}{$\begin{array}{c}\text { T } \\
\text { statistics }\end{array}$} & \multicolumn{1}{|c|}{$p$} & Result \\
\hline H1 & $\begin{array}{l}\text { Information } \rightarrow \\
\text { Brand Image }\end{array}$ & 0.127 & 0.061 & 2.097 & $0.037(*)$ & Supported \\
\hline H2 & $\begin{array}{l}\text { Interaction } \rightarrow \\
\text { Brand Image }\end{array}$ & 0.207 & 0.082 & 2.532 & $0.012(*)$ & Supported \\
\hline H3 & $\begin{array}{l}\text { Enjoyment } \rightarrow \\
\text { Brand Image }\end{array}$ & 0.531 & 0.081 & 6.572 & $\begin{array}{r}0.000 \\
(* * *)\end{array}$ & Supported \\
\hline H4 & $\begin{array}{l}\text { Brand Image } \rightarrow \\
\text { Intention }\end{array}$ & 0.756 & 0.036 & 21.181 & $\begin{array}{r}0.000 \\
(* * *)\end{array}$ & Supported \\
\hline
\end{tabular}

\section{Summary}

In sum, three characteristics of SNS marketing such as informativeness, interactivity, and playfulness have a positive influence on brand image, in turn, it positively affect repurchase intention. The findings give guidelines to implement the SNS marketing.

This work was supported by Dongguk University-Gyeongju.

\section{References}

1. Ann-Kristin Kupfer, A., ahler vor der Holte, N.P., K"ubler, R.V., and Hennig-Thurau, T. (2018), The Role of the Partner Brand'sSocial Media Power in Brand Alliances, Journal of Marketing, 82 (May 2018), 25-44. 
2. Hsieh, S.H. and Tseng, T.H. (2017), Playfulness in mobile instant messaging: Examining the influence of emoticons and text messaging on social interaction, Computers in Human Behavior, 69, 405-414.

3. Kim, J. and Lee, K.I. (2019), Influence of integration on interactivity in social media luxury brand communities, Journal of Business Research, 99, pp. 422-429.

4. Lee, J., Hong, I.B. (2016), Predicting positive user responses to social media advertising: The roles of emotional appeal, informativeness, and creativity, International Journal of Information Management, 36, pp. 360-373.

5. Lin, H. and Chang, C. (2018), What motivates health information exchange in social media? The roles of the social cognitive theory and perceived interactivity, Information \& Management, 55(6), 771-780.

6. Shin, J., Chae, H., and Ko, E. (2018), The power of e-WOM using the hashtag: focusing on SNS advertising of SPA brands, International Journal of Advertising, 37(1), pp. 71-85. 